\title{
Panel to gather intelligence on rival technology efforts
}

Paris. Luc Montagnier, of the Institut Pasteur in Paris, may need to swap his lab coat for a trench coat after his surprise appointment to a committee set up by the French government to improve the collection and distribution of 'economic intelligence'.

The Committee for Competitivity and Economic Security, as it is known, was set up earlier this month by presidential decree. Its seven members will be appointed to serve a three-year term of office by the prime minister, who will himself chair the committee.

In a report to President François Mitterrand accompanying the decree, Edouard Balladur, the current prime minister, claimed that changes in the geopolitical scene - particularly the globalization of business and technology - have made the committee necessary.

The committee's creation was prompted by a report on business intelligence by the Commissariat Général au Plan, a powerful agency made up of industrialists and representatives of trades unions and other public organizations. It concluded that the collection and distribution of economic intelligence had suffered from "multiple walls" and a "lack of coordination".

France has been spying on competitors' technologies and business strategies for years. But the commissariat argued that countries such as the United States, Germany, and Japan had much more advanced systems of 'legal' intelligence.

The United States has traditionally left the gathering of economic intelligence pri- marily to large companies. But the administration of President Bill Clinton has also begun to seek ways of improving the flow of information to those companies that might most benefit from it, even though - unlike Japan, for example - it has yet to use economic intelligence to support a national industrial policy.

The French committee appears similar to Japan's Cabinet Information and Research Office, and will be based within the General Secretariat of the National Defence (SGDN), which analyses intelligence, including technology developments, for the prime minister. Remy Pautrat, SGDN's deputy-secretary general, is a former head of the French counter-espionage agency DST.

Apart from Montagnier, the committee includes Bernard Esambert, a financier who is also president of the board of the Institut Pasteur, Philippe Jaffré, the chairman of Elf Aquitaine, and Henri Martre, honorary president of Aerospatiale and chairman of the working group that prepared the commissariat's report.

The creation of the committee has been generally welcomed by observers. But some also suspect a political motive. The Parisbased publication Intelligence Newsletter, for example, points out that many members of the committee are close to Balladur, who nominated them just before he was eliminated from the presidential elections last Sunday. The apparent political dimension of some of these appointments may limit the committee's effectiveness. Declan Butle

\section{Glaxo researchers move to new home}

\begin{abstract}
London. Glaxo Wellcome, the world's largest pharmaceutical company after the recent merger between Glaxo and the Wellcome Foundation, last week opened a $£ 700$ million (US\$1.1 billion) medicines research centre in Stevenage (right), north of London.
\end{abstract}

The centre has been designed to bring together drug discovery teams from a range of disciplines, including organic and analytical chemistry, microbiology, bioinformatics, genomics, pharmacology and cellular and molecular biology.

By the end of June, Glaxo Wellcome will have moved 1500 scientists and support staff on to the site, the completion of a project which began

\section{US physicists seek construction role in Europe's LHC}

Washington. An informal consortium of three US laboratories is working out how the United States could contribute to the construction of the proposed Large Hadron Collider (LHC) at the European Laboratory for Particle Physics (CERN) in Geneva.

Experts from the Brookhaven National Laboratory, Fermilab and the Lawrence Berkeley Laboratory have started talks with CERN about a material US contribution to the accelerator project which could be worth between $\$ 200$ million and $\$ 400$ million, according to Peter Limon of Fermilab.

The contribution would probably be made in the form of engineered components, such as superconducting magnets. US high-energy physicists argue that such involvement in the construction of the LHC is essential if the United States is to be fully engaged in the project.

US physicists are already involved in the design of two detectors to be installed at the LHC - Atlas and CMS - but want their involvement to go further. "No-one has said we can't be part of the detectors if we aren't part of building the machine," Limon last week told a meeting of the American Physical Society in Washington. But without involvement in the construction "it would be the last time" that the United States would be invited to share in the scientific output of such an international collaboration.

The physics community and its paymaster, the Department of Energy, are united behind such involvement, according to Sidney Drell, deputy director of the Stanford Linear Accelerator Center in California. Last year, Drell prepared a report for the US government on the future of high-energy physics. This suggested that LHC could be 음 given up to $\$ 400$ million in US support without hurting domestic programmes. But he admits uncertainty over whether Congress, which will ultimately make the decision, would be so supportive.

The Department of Energy has asked for relatively small budgets of around $\$ 10$ million for each of the next two financial years to support work related to the LHC. Only in the year after that - 1998 - would a more substantial amount be needed to support actual LHC construction. So Congress need not decide on the matter for two years.

According to Limon, one option being considered for US participation would involve supplying all the quadrupole magnets used to focus the particle beam. "No dollar bills would actually go to CERN," he said. "The money stays here and the goods go there". He claimed that Japan is considering contributing up to $\$ 100$ million for the construction of the accelerator, and $\$ 50$ million for its detectors. Colin Macilwain seven years ago. "Stevenage is one part of our overall strategy designed to leading Glaxo research official.

The centre has been designed to encourage researchers in different disciplines to interact, for example by using numerous meeting places known as 'nodes' - on the main thoroughfares between buildings. 